\title{
Detekcija bakterija koje reduciraju sulfate i ostalih uzgojivih fakultativnih bakterija u zubnim tkivima
}

\section{Detection of Sulphate-Reducing Bacteria and Others Cultivable Facultative Bacteria in Dental Tissues}

\footnotetext{
${ }_{1}^{1}$ Zavod za patologiju Medicinskog fakulteta Sveučilišta Fluminense, Rio de Janeiro, Brazil Department of Pathology, Medical School, Fluminense Federal University, Rio de Janeiro, Brazil.

2 Stomatološki fakultet Sveučilišta Estácio de Sá, Rio de Janeiro, Brazil

Dental School, Estácio de Sá University, Rio de Janeiro, Brazil.

${ }^{3}$ Nacionalni tehnološki laboratorij za biokoroziju i biorazgradivost

Laboratory of Biocorrosion and Biodegradation, National Institute of Technology.

Stomatološki fakultet Sveučilišta Fluminense, Rio de Janeiro, Brazil

Stomatologist, Fluminense Federal University, Rio de Janeiro, Brazil.
}

Sažetak

Svrha: Željelo se detektirati bakterije koje reduciraju sulfate (BRS) i procijeniti moguću povezanost između BRS-a i fakultativnih bakterija na različitim mjestima u usnoj šupljini s različitim stanjem parodonta. Metode: Za istraživanje je od osmero pacijenata uzeto devet uzoraka (od jednog pacijenta uzeta su dva) s različitih mjesta u usnoj šupljini. Skupljeni su s pomoću modificiranog medija Postgate E namijenjenog uzgoju, rastu i izolaciji BRS-a. Osim toga upotrijebljena je i reducirana otopina za anaerobne bakterije kao otopina za transport fakultativnih bakterija identificiranih s pomoću lančane reakcije polimeraze te sekvencije gena $16 \mathrm{~S}$ rRNK. Rezultati: BRS je pronađen u trima uzorcima - u fragmentu korijena, u fragmentu korijena i u zdravom zubu s vertikalnim gubitkom kosti i pomičnošću treće razine, te u zdravom zubu izvađenom zbog ortodontskih razloga. Kod posljednjeg pacijenta fakultativna bakterija identificirana je kao Lactobacillus casei. Ostale bakterije bile su Kurthia gibsonii (pacijent 5) i Pseudomonas aeruginosa (pacijent 7). Zaključak: Otkrivanje BRS-a na različitim zubnim tkivima s izrazitim parodontnim problemima upozorilo je na to da su potrebna nova istraživanja kako bi se otkrila prava uloga BRS-a u oralnoj mikroflori. Također smo, osim BRS-a, u istom uzorku mogli potvrditi i prisutnost Lactobacillus casei.
Zaprimljen: 16. svibnja 2013. Prihvaćen: 30. siječnja 2014.

Adresa za dopisivanje Dr. Fabiano Luiz Heggendorn Rua Feliz da Cunha 11, ap. 806, Tijuca CEP 20260-300, Rio de Janeiro tel. (21) 94119341. fabianohegg@gmail.com

Ključne riječi parodontitis; sumpor-reducirajuće bakterije; Desufovibrio
Uvod

Bakterije koje reduciraju sulfate (BRS) isključivo su anaerobne s optimalnom temperaturom između 25 i $44^{\circ} \mathrm{C}$ i rasponom pH izmedu 5,5 i 9,0. Danas se zna za dvadesetak podvrsta BRS-a, primjerice za Desulfovibrio, Desulfomonas, Desulfotomaculum, Desulfolobus, Desulfobacter, Desulfococus, Desulfosarcina (1). Te izbirljive mikroorganizme možemo pronaći u okolišu - u slatkoj vodi i slanim močvarama ili u ljudskom tijelu, ponajprije u crijevnoj mikroflori gdje se najčešce nalazi Desulfovibrio desulfuricans $(2,3)$.

Sefer i Câlinescu (4), (1969.), u jednom od prvih radova o toj temi, otkrili su BRS, uz Streptococcus sp., na sedam izvađenih zuba zbog propadanja tvrdoga zubnog tkiva. Dokazali su Desulfovibrio sp. i u strugotinama karioznog dentina. Istraživanja BRS-a nastavljena su tek tri desetljeća poslije kada je u jednoj studiji opisana njegova pojava na bukalnoj sluznici, jeziku, u slini te u sub- i supragingivnom biofilmu $(5-9)$.

\section{Introduction}

Sulphate-reducing bacteria (SRB) are strict anaerobes, with an optimal temperature range of between 25 and $44^{\circ} \mathrm{C}$ and a $\mathrm{pH}$ between 5.5 and 9.0. There are currently over 20 well know generas such as Desulfovibrio, Desulfomonas, Desulfotomaculum, Desulfolobus, Desulfobacter, Desulfococus, Desulfosarcina, among others (1). These fastidious microorganisms can be found in environments such as freshwater and salt marshes or in the human body, mainly in the intestinal microbiota, where the species Desulfovibrio desulfuricans is frequently detected $(2,3)$.

In a pioneering work, Sefer and Cälinescu (4),(1969) reported the presence of SRB associated with Streptococcus sp. in seven teeth extracted due to extensive tooth decay. Furthermore they reported the presence of Desulfovibrio sp. in carious dentine scrapings. Only after almost three decades, studies on the presence of SRB in the oral cavity resumed, with a study describing the occurrence of SRB in the buccal 
Boopathy i suradnici. (6) otkrili su BRS u uzorku tkiva uzetom iz parodontnih džepova 9 od 17 pacijenata te su između ostalih bakterija izolirali i Desulfovibrio spp. U ostalim istraživanjima upozoreno je da je BRS brojniji u subgingivnom plaku negoli na stražnjem i prednjem dijelu jezika, u bukalnoj i vestibularnoj sluznici te supragingivnom pla$\mathrm{ku}(7-9)$.

U nekoliko istraživanja ističe se povezanost između parodontnog statusa i prisutnosti BRS-a u oralnoj mikroflori u kojoj su Desulfovibrio fairfieldensis i Desulfovibrio desulfuricans izolirani kao uzročnici parodontitisa, iako se nije znao točan utjecaj tih bakterija na gubitak kosti $(7,10-13)$. Te iste bakterije stvaraju agresivnije komplekse $s$ drugim parodontnim patogenima kao što su $T$. denticola, T. forsythus, $P$. gingivalis i metalogene bakterije $(9-14)$.

Svrha ovog istraživanja bila je otkriti prisutnost BRS-a i procijeniti njegovu moguću povezanost s fakultativnim bakterijama nađenima na raznim mjestima u oralnoj šupljini $s$ različitim stanjem parodonta.

\section{Materijali i metode}

Istraživanje je obavljeno na devet uzoraka uzetih od osam pacijenata (od pacijenta broj 4 uzeta su dva uzorka s različitih lokacija) (tablica 1.) Pritom smo se koristili modificiranim medijem Postgate E koji je namijenjen rastu i izolaciji BRS-a (1), a sadržava ( $\mathrm{g} / \mathrm{L}$ destilirane vode): $\mathrm{KH}_{2} \mathrm{PO}_{4}(0,5)$; $\mathrm{NH}_{4} \mathrm{Cl}(1,0) ; \mathrm{Na}_{2} \mathrm{SO}_{4}(, 10) ; \mathrm{CaCl}_{2} 2 \mathrm{H}_{2} \mathrm{O}(0,67) ; \mathrm{MgCl}_{2}$ mucosa, tongue, saliva, subgingivial and supragingivial biofilms (5-9).

As well as tissue samples from periodontal pockets, Boopathy et al. (6), identified the presence of SRB in 9 to 17 patients with periodontitis, identifying Desulfovibrio spp. among the samples tested. Other studies indicate a greater number of SRB in subgingivial biofilms when compared to the posterior and anterior tongue, the buccal mucosa, vestibular mucosa and the supragingivial biofilm (7-9).

Several studies indicate a strong association between periodontal status and the presence of SRB in the oral microbiota, with Desulfovibrio fairfieldensis and Desulfovibrio desulfuricans species being reported as causative agents of periodontitis, without a true understanding of their role in bone loss $(7,10-13)$. Such bacterial species can form a more aggressive complex in periodontal diseases when associated with other periodontal pathogens such as T. denticola, T. forsythus, P. gingivalis and metallogenic bacteria (9-14).

The objective of this study was to detect for the presence of SRB and evaluate the possible association between SRB and cultivable facultative bacteria of oral sites with different periodontal conditions.

\section{Material and Methods}

The study was carried out on 9 samples from different oral sites in 8 patients (in the patient number 4, two samples were collected from two different oral sites) (Table 1). Material was collected using a modified Postgate E culture medium, indicated for the growth and isolation of SRB (1), composed of the following ( $\mathrm{g} /$ Litre of distilled water): $\mathrm{KH}_{2} \mathrm{PO}_{4}$

\begin{tabular}{|c|c|c|c|c|c|c|}
\hline $\begin{array}{c}\text { Pacijent } \bullet \\
\text { Patient }\end{array}$ & $\begin{array}{l}\text { Spol } • \\
\text { Sex }\end{array}$ & $\begin{array}{c}\text { Dob• } \\
\text { Age }\end{array}$ & $\begin{array}{l}\text { Pušač • } \\
\text { Smoker }\end{array}$ & $\begin{array}{c}\text { Sistemska bolest } \\
\text { Systemic disease }\end{array}$ & \begin{tabular}{|c|} 
Prikupljeni \\
materijal $\bullet$ \\
Material collected
\end{tabular} & Opis mjesta $\bullet$ Site description \\
\hline 1 & M & 21 & $\mathrm{~N}$ & $\mathrm{~N}$ & $\begin{array}{c}\text { Strugotine karijesa } \\
\text { Caries scraping }\end{array}$ & $\begin{array}{l}\text { Zub } 36 \text { s dubokim karijesom saniranim amalgamom } \bullet \\
\text { Tooth } 36 \text { with deep caries restored with amalgam }\end{array}$ \\
\hline 2 & $\check{Z} \bullet F$ & 59 & & $\begin{array}{l}\text { Hipotiroidizam • } \\
\text { Hypothyroidism }\end{array}$ & $\begin{array}{l}\text { Fragment korijena } \\
\text { Root fragment }\end{array}$ & $\begin{array}{l}\text { Zub } 15 \text { s ranijim apscesima, predviden za ekstrakciju } \bullet \\
\text { Tooth } 15 \text {, indicated for extraction, with a history of abscesses }\end{array}$ \\
\hline 3 & M & 50 & $\mathrm{~N}$ & $\mathrm{~N}$ & $\begin{array}{l}\text { Fragment korijena } \\
\text { Root fragment }\end{array}$ & $\begin{array}{l}\text { Zub } 35 \text { s ranijim apscesima, predviden za ekstrakciju } \bullet \\
\text { Tooth 35, indicated for extraction, with a history of abscesses }\end{array}$ \\
\hline \multirow{2}{*}{4} & M & 46 & $\mathrm{~N}$ & $\mathrm{~N}$ & $\begin{array}{l}\text { Fragment korijena } \\
\text { Root fragment }\end{array}$ & $\begin{array}{l}\text { Zub } 25 \text { s ranijim apscesima, predviđen za ekstrakciju } \bullet \\
\text { Tooth } 25 \text {, indicated for extraction, with a history of abscesses }\end{array}$ \\
\hline & & & & & $\begin{array}{l}\text { Zdravi zub } \\
\text { Healthy tooth }\end{array}$ & $\begin{array}{l}\text { Zub } 223 \text {. stupnja pomičnosti (gubitak alveoralne kosti) } \\
\text { Tooth } 22 \text { with dental mobility degree of } 3 \text { (advanced bone loss) }\end{array}$ \\
\hline 5 & $\check{\mathrm{Z}} \cdot \mathrm{F}$ & 83 & $\mathrm{~N}$ & $\begin{array}{l}\text { Hipertenzija i } \\
\text { osteoporoza } \\
\text { Hypertension and } \\
\text { osteoporosis }\end{array}$ & $\begin{array}{l}\text { Zub nosač } \\
s \text { mostom } \\
\text { Abutment tooth } \\
\text { with fixed bridge }\end{array}$ & $\begin{array}{l}\text { Zub } 163 \text {. stupnja pomičnosti } \bullet \\
\text { Tooth } 16 \text { with dental mobility degree of } 3\end{array}$ \\
\hline 6 & $\check{Z} \cdot \mathrm{F}$ & 46 & $\mathrm{~N}$ & $\mathrm{~N}$ & Bioptat $\bullet$ Biopsy & $\begin{array}{l}\text { Bioptat endodontske lezije zuba } 11 \bullet \\
\text { Endodontic lesion biopsy by paraendodontic surgery of tooth } 11\end{array}$ \\
\hline 7 & $\check{Z} \cdot \mathrm{F}$ & 19 & $\mathrm{~N}$ & $\mathrm{~N}$ & $\begin{array}{l}\text { Papirnati štapić } \\
\text { Paper point }\end{array}$ & $\begin{array}{l}\text { Sterilni papirnati štapić koji je } 3 \text { sekunde bio u kanalu korijena } \\
\text { tijekom druge sekcije pod potpunom izolacijom } \bullet \\
\text { Sterile paper cone, inserted for } 3 \text { seconds to the root canal of a } \\
\text { tooth, during the second section under absolute isolation }\end{array}$ \\
\hline 8 & M & 22 & $\mathrm{~N}$ & $\mathrm{~N}$ & $\begin{array}{l}\text { Zdravi zub } \bullet \\
\text { Healthy tooth }\end{array}$ & $\begin{array}{l}\text { Zub } 48 \text { (bez gubitka kosti) predviden za ekstrakciju } \bullet \\
\text { Tooth } 48 \text { (without bone loss) indicated for extraction because of } \\
\text { orthodontic treatment }\end{array}$ \\
\hline
\end{tabular}


$6 \mathrm{H}_{2} \mathrm{O}(, .68)$; natrijev laktat $(7,0)$, ekstrakt kvasca $(1,0)$, askorbinsku kiselinu $(0,1)$; agar-agar $(1,9), \mathrm{NaCl}(5,0)$, rezasurin $(4,0 \mathrm{~mL})$ i $\mathrm{FeSO}_{4} 7 \mathrm{H}_{2} \mathrm{O}(0,5)$. $\mathrm{Uz}$ to, korištena je reducirajuća otopina za anaerobne bakterije kao transportni medij za fakultativne bakterije koja je sadržavala ( $\mathrm{g} / \mathrm{L}$ destilirane vode) natrijev tioglikolat $(0,124)$; askorbinsku kiselinu $(0,1) ; \mathrm{NaCl}(5,0)$ i rezasurin $(4,0 \mathrm{ml}) \cdot \mathrm{pH}$ medija iznosio je 7,6 s NaOH-om.

\section{Identificiranje BRS-a i izoliranje fakultativnih bakterija}

Čim su uzorci skupljeni svaki je odmah stavljen u posebnu epruvetu s reducirajućom otopinom za anaerobne bakterije. Nakon što ih se protreslo desetak sekundi, $1,0 \mathrm{ml}$ otopine inokuliran je u modificirani medij Postgate E.

Zatim su uzorci u reduciranoj otopini od po $1 \mathrm{~mL}$ preneseni u hranjivi medij te prebrojeni. Nakon toga su kolonije izolirane te inkubirane od 24 do 48 sati i ponovno su inokulirane u hranjivom mediju za naknadnu biomolekularnu identifikaciju vrsta bakterija.

Uzorci inokulirani u posebnim epruvetama koje su sadržavale modificirani medij Postgate E bile su inkubirane 28 dana na temperaturi od $30^{\circ} \mathrm{C}$. Medij je pregledan mikroskopski te je uočena diskoloracija zbog stvaranja crnog taloga raspršenog u mediju, što je upućivalo na prisutnost BRSa. Nakon 28 dana medij je potpuno pocrnio, a to je značilo da sadržava BRS. Talog je nastao nakon vezanja iona željeza prisutnih u modificiranom mediju Postgate E zato što su bakterije reducirale sulfat pa se željezo vezalo za sulfide (1). Uzorci bez BRS-a bili su ružičasti ili prozirno bijeli, što je upućivalo na rast ostalih anaerobnih bakterija koje ne reduciraju sulfate.

\section{Biomolekularna identifikacija fakultativnih bakterija}

Fakultativne bakterije mogle su se izolirati jedino iz uzoraka pacijenata 5, 7 i 8 kod kojih su provedeni protokoli za njihovo otkrivanje. Pritom je korišsten set za ekstrakciju DNK MOBio UltraClean Microbial DNA ${ }^{\circledR}$. Ekstrahirani DNK proveden je kroz elektroforezu na 1-postotnom agargelu obojenom SYBR Safeom. ${ }^{\circledR}$ Nakon ekstrakcije je gen $16 S$ RNK (1500bp) pojačan PCR-om s univerzalnim primerima za bakterije SAdir (5'-AGAGTTTGATCATGGCTCAGA-3') i S17rev (5'-GTTACCTTGTTACGACTT-3'). Amplifikacija je obavljena sustavom GeneAmp PCR System 9700 (Applied Biosystems) te je uključen inicijalni ciklus denaturacije ( $94^{\circ} \mathrm{C}$ tijekom 5 minuta), 30 srednjih ciklusa denaturacije $\left(94^{\circ} \mathrm{C}\right.$ tijekom 30 sekundi), prekaljivanje $\left(55^{\circ}\right.$ $\mathrm{C}$ tijekom 30 sekundi) i dva finalna ciklusa $\left(72^{\circ} \mathrm{C}\right.$ tijekom 30 sekundi te $72^{\circ} \mathrm{C}$ tijekom 5 minuta).

Ishod svake reakcije PCR-a analiziran je s pomoću elektroforeze na agarozi (1\%), obojen bojilom SYBR Safe i nakon toga pročišćen UltraCleanom ${ }^{\circledR}$ PCR Clean-up ${ }^{\circledR}$ (MOBio). Nakon toga je kvantiteta i čistoća rezultata PCR-a određena optičkom spektrofotometrijom (NanoDrop ${ }^{\circledR}$ ND1000 UV-Vis - Thermo Scientific).
(0.5); $\mathrm{NH}_{4} \mathrm{Cl}(1.0) ; \mathrm{Na}_{2} \mathrm{SO}_{4}(1.0) ; \mathrm{CaCl}_{2} 2 \mathrm{H}_{2} \mathrm{O}$ (0.67); $\mathrm{MgCl}_{2} 6 \mathrm{H}_{2} \mathrm{O}$ (1.68); sodium lactate (7.0); yeast extract (1.0); ascorbic acid (0.1); agar-agar (1.9); $\mathrm{NaCl}(5.0)$; rezasurina $(4.0 \mathrm{~mL}) ; \mathrm{FeSO}_{4} 7 \mathrm{H}_{2} \mathrm{O}(0.5)$. In addition, a reducing solution for anaerobic bacteria was used as a transport solution for facultative bacteria, consisting of the following $(\mathrm{g} / \mathrm{Li}-$ tre of distilled water): sodium thioglycolate (0.124); ascorbic acid (0.1); $\mathrm{NaCl}(5.0)$; and rezasurina $(4.0 \mathrm{ml})$. The $\mathrm{pH}$ of the medium was adjusted to 7.6 with $\mathrm{NaOH}$.

\section{Identifying SRB and isolating facultative bacteria}

Immediately after collection, each sample was placed in separate tubes containing reducing solution for anaerobic bacteria, shaken for 10 seconds and $1.0 \mathrm{ml}$ of this solution was inoculated in modified Postgate E medium.

Subsequently, samples in reducing solution were transferred, in $1.0 \mathrm{ml}$ aliquots, to nutrient broth culture medi$\mathrm{um}$, and the striation method using plate count medium was performed. After verifying the isolation of colonies, incubated from 24 to $48 \mathrm{hrs}$, they were again inoculated in nutrient broth medium for subsequent biomolecular identification of the species present.

Samples inoculated in separate tubes containing modified Postgate E medium were incubated for 28 days at $30^{\circ} \mathrm{C}$. The media was macroscopically inspected, observing discoloration due to the formation of black precipitates dispersed throughout the culture medium when positive for the presence of SRB. Then, after 28 days, the media with black color confirmed the presence of SRB. The precipitates were representative of the binding of the iron ion present in modified Postgate $\mathrm{E}$ culture medium with the reduction of sulphate by SRB to form iron sulphide (1). Samples negative for the presence of SRB developed a pink or white-transparent coloration, indicating the growth of other anaerobic bacteria that do not reduce sulphate.

\section{Biomolecular identification of facultative bacteria}

The isolation of facultative bacteria was possible only for samples from patients numbers 5, 7 and 8 , where the protocol was carried out to identify these microorganisms. The MOBio UltraClean Microbial DNA ${ }^{\circledR}$ kit was used to extract DNA from the sample. The extracted DNA was visualized by electrophoresis of a $1 \%$ agarose gel stained by SYBR Safe ${ }^{\circledR}$. After the extraction step, the 16S RNA gene (1500bp) was amplified by PCR using the universal primers for bacteria: SAdir (5'-AGAGTTTGATCATGGCTCAGA-3') and S17rev (5'-GTTACCTTGTTACGACTT-3'). Amplification was performed in a GeneAmp PCR System $9700^{\circ}$ thermocycler (Applied Biosystems) and included an inital denaturation cycle $\left(94^{\circ} \mathrm{C}\right.$ for 5 minutes); 30 intermediate denaturation cycles $\left(94^{\circ} \mathrm{C}\right.$ for 30 seconds), annealment $\left(55^{\circ} \mathrm{C}\right.$ for 30 seconds) and an extension cycle $\left(72^{\circ} \mathrm{C}\right.$ for 30 seconds) and one final extension cycle $\left(72^{\circ} \mathrm{C}\right.$ for 5 minutes).

All PCR products were analysed by agarose gel (1\%) electrophoresis, stained by SYBR Safe and then purified with the UltraClean ${ }^{\circledR}$ PCR Clean-up ${ }^{\circledR}$ kit (MOBio). After this step, the quantity and purity of the PCR products was determined 
Sekvencioniranje rezultata PRC-a obavljeno je automatskim uređajem MEGABACE 1000, odnosno s pomoću Sector of DNA Sequncinga. Dobiveni rezultati analizirani su u programu Chromas Lite, version 2,01 (McCarthy, 1996, www.tecnelysium.com.au) te su sekvencije DNK uspoređene $s$ već poznatim sekvencijama iz baze podataka Genbank (www.ncbi.nlm.nih.gov).

Usporedivanje podjednakosti u sekvencijama uzoraka 16S rRNK provedeno je BLAST-om (Basic Alignment Search Tool, http://genome.eerie.fr/bin/blast-guess.cgi.) koji je otkrio izolirane bakterijske vrste.

\section{Rezultati}

Od osam pacijenata uključenih u ovo istraživanje, samo su tri bila pozitivna na BRS (tablica 2.). Od prvog pacijenta (broj 2) uzorak je uzet s fragmenta korijena, od drugog pacijenta (broj 4) izdvojen je s fragmenta korijena i sa zdravog zuba s vertikalnim gubitkom kosti i trećim stupnjem pomičnosti, a od trećeg pacijenta (broj 8) uzet je sa zdravog zuba ekstrahiranog u ortodontske svrhe. Kod posljednjeg pozitivnog pacijenta izolirana je fakultativna bakterija Lactobacillus casei. Ostale fakultativne bakterije pronađene su kod pacijenta broj 5 (Kurthia gibsonii) i broj 7 (Pseudomonas aeruginosa) (tablica 2.). by optical density spectrophotometry $\left(\mathrm{NanoDrop}^{\circledR} \mathrm{ND}\right.$ 1000 UV-Vis - Thermo Scientific).

Sequencing of the PCR products was carried out by the Sector of DNA Sequencing, in a MEGABACE 1000 automatic sequencer. The resulting sequence electropherograms were analysed by the program Chromas Lite, version 2.01 (McCarthy, 1996, www.tecnelysium.com.au). The DNA sequences obtained were compared to those already in Genbank (www.ncbi.nlm.nih.gov).

The search for sequence similarity of the $16 \mathrm{~S}$ ribosomal RNA gene of the isolated samples was carried out using BLAST (Basic Alignment Search Tool, http://genome.eerie. $\mathrm{fr} /$ bin/blast-guess.cgi.) revealing the bacterial species isolated.

\section{Results}

Of the eight patients included in this study, only three were positive for the presence of SRB (Table 2). In the first patient (number 2), the sample was isolated from a root fragment; in the second (number 4), from a root fragment and a healthy tooth with vertical bone loss and with a mobility degree of 3 ; and in the third (number 8), a healthy tooth extracted for orthodontic purposes. In the final patient sample, Lactobacillus casei, a cultivable facultative bacterial species was identified. Other facultative bacterial species were identified in patient 5 (Kurthia Gibsonii) and patient 7 (Pseudomonas aeruginosa) (Table 2).

\begin{tabular}{|c|c|c|c|}
\hline $\begin{array}{c}\text { Pacijent } \\
\text { Patient }\end{array}$ & Uzorak • Sample & SRB & FAB \\
\hline 1 & Strugotine karijesa $\bullet$ Caries scapings & - & \\
\hline 2 & Fragment ekstrahiranog korijena $\bullet$ Extracted root fragment & + & \\
\hline 3 & Fragment ekstrahiranog korijena $\bullet$ Extracted root fragment & - & \\
\hline \multirow{2}{*}{4} & Fragment ekstrahiranog korijena $\bullet$ Extracted root fragment & + & \\
\hline & Zdravi zub $\bullet$ Healthy tooth & + & \\
\hline 5 & Zub nosač s mostom $\bullet$ Abutment tooth with fixed bridge & - & Kurthia gibsonii \\
\hline 6 & Bioptat $\bullet$ Biopsy & - & \\
\hline 7 & Papirnati štapić $\bullet$ Paper point & - & Pseudomonas aeruginosa \\
\hline 8 & Zdravi zub $\bullet$ Healthy tooth & + & Lactobacillus casei \\
\hline
\end{tabular}

$(-)$ Negativno $\bullet$ Negative; $(+)$ Pozitivno $\bullet$ Positive; FAB = Fakultativni anaerobi $\bullet$ Facultative Anaerobic Bacteria

\section{Rasprava}

Bisson-Boutelliez i suradnici (11) otkrili su da invazivni kapacitet bakterije Desulfovibrio spp. potiče u epitelnim stanicama izlučivanje citokina IL-6 i IL-8. Prema njihovu mišljenju, takvi dokazi potvrđuju činjenicu o nastanku i napredovanju parodontne bolesti. Ti su istraživači također povezali nakupljanje sulfata kao konačnog metaboličkog proizvoda BRS-a u parodontnim džepovima i smrt parodontnih stanica (7). Tu tvrdnju podupire činjenica da je BRS potvrđen u deset uzoraka subgingivnog plaka uzetoga od različitih pacijenata $s$ parodontitisom te da su te iste bakterije pronađene u barem jednom džepu kod 64 posto pacijenata s parodontitisom $(7,8)$.

\section{Discussion}

Bisson-Boutelliez et al. (11), (2010) reported that the invasive capacity of Desulfovibrio spp. in oral epithelial cells induced the secretion of cytokines, IL- 6 and IL- 8 by these cells. According to the author, such evidence contributes to the initialization and perpetuation of periodontal disease. In addition, the author also related the accumulation of sulphate, as a final metabolic product of SRB in periodontal pockets, as responsible for causing cellular damage to cells (7). This is demonstrated by the isolation of sulphate-reducing bacteria in 10 subgingivial plaque samples from various patients with periodontitis and no less than one periodontal pocket in $64 \%$ of patients with periodontitis $(7,8)$. 
U ovom istraživanju četiri od devet uzoraka bilo je pozitivno na BRS $(66,67 \%)$, što upućuje na to da su ove bakterije možda dio normalne oralne mikroflore s potencijalom da uzrokuju parodontnu bolest. Takav slučaj otkriven je kod jednog pacijenta koji je imao BRS na dva različita mjesta na zubu 35 i na zubu 31 . Na zubu 31 radilo se o velikom razaranju parodonta i o vertikalnom gubitku kosti, što upućuje na to da je BRS možda utjecao na parogenezu parodontne bolesti. To se moglo vidjeti i kod pacijenata 2 i 4 kod kojih su uzorci bili uzeti sa zuba s različitim stupnjevima parodontne bolesti. Ovi rezultati u skladu su s rezultatima Langendijka i suradnika. (7) koji su uočili veću količinu BRS-a kod pacijenata s parodontnim džepovima i krvarenjem tijekom sondiranja, $s$ raznim koštanim defektima, otvorenim furkacijama i endodontskim komplikacijama. To ih je navelo na zaključak da postoji izravna povezanost između dubine džepova i prisutnosti BRS-a. Willis i suradnici (5) otkrili su veću učestalost BRS-a u slini nego u sub- i supragingivnom plaku, prednjem i stražnjem dijelu jezika te na oralnoj sluznici.

$\mathrm{Na}$ mjestima koja nisu u izravnom doticaju s oralnim okružjem nije izoliran BRS kao što je, primjerice, bioptat iz endodontske lezije ili korijenskog kanala. To upućuje na činjenicu da je potrebno izlaganje oralnom okružju kako bi se kolonizirao BRS.

Jedno od važnih svojstava BRS-a je prianjanje na različite podloge na kojima stvara plak s ostalim bakterijama (15, 16). Treba istaknuti da, kad se nalazi u oralnom mediju, BRS može kolonizirati različita mjesta u usnoj šupljini što je i vidljivo kod pacijenta 4 kod kojega su bakterije kolonizirale različita udaljena mjesta (zub 35 i 31 ).

Bakterija Lactobacillus spp. usko je povezana s nastankom karijesa i nalazi se u oralnoj mikroflori, plaku i na površinama zuba te mijenja razinu mliječne kiseline u mikrookolišu (17). Lactobacillus casei može se pronaći u supragingivnom aproksimalnom plaku (17) i biofilmu (18). Smanjenje $\mathrm{pH}$ vrijednosti koje uzrokuje Lactobacillus spp. potiče metaboličku inhibiciju te povećava broj bakterija koje preživljavaju u novonastalim uvjetima (19). Unatoč svemu ovo je istraživanje potvrdilo BRS i Lactobacillus casei u istom uzorku, što može upućivati na simbiotsku aktivnost tih mikroorganizama. Aerobne bakterije pogoduju BRS-u jer svojim metabolizmom stvaraju anaerobne uvjete za metabolizam i rast BRS-a (16). Lactobacillus casei fakultativna je bakterija koja proizvodi mliječnu kiselinu (18) kojom se BRS koristi kao izvorom organskoga ugljičnog laktata (1), što je zapravo sol mliječne kiseline. Langendijk i suradnici (8) istraživali su oksidaciju laktata u prisutnosti sulfata u deset podvrsta BRS-a izoliranih iz oralne mikroflore.

Mnogo crijevnih bakterija proizvodi laktate, što stimulira BRS na proizvodnju sulfata u debelom crijevu (20). Newton i suradnici (21) procijenili su utjecaj Desulfovibrio desulfuricans na populaciju trajnih crijevnih bakterija kao što je Lactobacillus acidophilus. U ovom istraživanju zabilježena je velika redukcija laktata, koji služi kao važan donor elektrona potrebnih bakteriji Desulfovibrio spp., te velika redukcija u populaciji bakterije Lactobacillus acidophilus.
In the current study, of the nine samples, four were positive for the presence of SRB (66.67\%), indicating that this bacterial group may be a part of the normal oral microbiota while also potentially being associated with periodontal disease. This was observed in one patient where SRB was found in two distinct sites, tooth 35 and 31 . However the sample from tooth 31 had severe periodontal destruction, with vertical bone loss, presenting the possibility that SRB has a role in the pathogenesis of periodontal disease. The same was similar for two other samples analyzed from root fragments (patients numbers 2 and 4), where clinically these teeth presented different degrees of periodontal involvement. These findings are in accordance with Langendijk et al. (7), who reported a higher prevalence of SRB in patients with periodontal pockets and bleeding upon probing and in patients with various angular bone defects, furcation and endodontic complications, observing a direct relationship between the pocket depth and the presence of SRB. Willis et al. (5), identified a greater prevalence of SRB in saliva when compared with sub- and supragingivial biofilms, the anterior and posterior tongue and the oral mucosa.

In sites without direct contact with the oral environment, SRB was not isolated from the endodontic lesion biopsy or the root canal paper cone, which highlights the need for oral microbiota exposure for potential colonisation by SRB.

One of the important characteristics of SRB is its ability to associate with different types of surfaces where it constructs a cooperative consortium with other types of bacteria to form a biofilm $(15,16)$. It may be suggested that once present in the oral microbiota, different oral sites can be colonized by SRB, as demonstrated by patient 4, with the colonization of SRB in distant sites (tooth 35 and 31).

The Lactobacillus spp., which is strongly associated with dental caries is present in the oral microbiota, dental biofilm and the dentine surface and changes the level of lactic acid in these microenvironments (17), while the species Lactobacillus casei can be found in supragingivial interproximal plaque (17) and dental biofilms (18). The reduction of $\mathrm{pH}$ in the microenvironment caused by Lactobacillus spp. results in the metabolic inhibition and increase of bacteria present in the oral microbiota of this microenvironment (19). However, the current study identified SRB and Lactobacillus casei in the same sample, which may indicate a possibility symbiotic relationship between these microorganisms. In association with aerobic bacteria, SRB benefits the formation of an anaerobic microenvironment in the biofilm caused by the metabolism of the aerobic bacteria present, where oxygen consumption will ensure a reduction in the necessary conditions for the growth of SRB, leading to maximum metabolic activity (16). Lactobacillus casei is a facultative bacteria that produces lactic acid (18) which can be used by the SRB as a source of organic carbon lactate (1), which is a salt of lactic acid. Langendijk et al. (8), reported the oxidation of lactate in the presence of sulphate in ten SRB strains isolated from the oral microbiota.

Many intestinal bacteria produce lactate which stimulates the production of sulphate by the SRB present in the colon (20). Newton et al. (21), evaluated the effect of De- 
Rezultati ovog istraživanja moraju se oprezno interpretirati zbog malog uzorka. Upravo zato se i ne mogu pronaći poveznice izmedu BRS-a i ostalih bakterija.

Također je bilo moguće dokazati veću pojavnost BRS-a u uzorcima sline kod pacijenata s gastritisom i parodontitisom (22). Metodologija korištena u ovom istraživanju bila je usmjerena više na detekciju mjesta na kojima djeluje BRS. Prisutnost BRS-a u različitim oralnim tkivima $s$ različitim parodontnim statusom upućuje na to da su potrebna nova istraživanja kako bi se ustanovila njegova prava uloga u oralnoj mikroflori. Osim toga bilo je moguće $u$ istom uzorku potvrditi prisutnost Lactobacillus casei i BRS-a.

\section{Zahvala}

Autori zahvaljuju svim pacijentima koji su sudjelovali u istraživanju. Rad su poduprli Zaklada za postdoktorsko obrazovanje (CAPES) i Nacionalni institut za tehnologiju (LA$\mathrm{BIO}$ i DCOR).

\section{Sukob interesa}

Svi autori potvrdili su da nisu u sukobu interesa. sulfovibrio desulfuricans on intestinal bacterial populations in continuous cultures, among these, Lactobacillus acidophilus. This study noted a great reduction of lactate, which is an important electron donor for Desulfovibrio sp., as well as a significant reduction in the population of Lactobacillus acidophilus species.

The findings here need to be considered with caution because the small number of samples. In this way, it could not be able to establish associations of SRB with other cultivable bacteria. Therefore, it is necessary to increase the number of samples for future effective conclusions.

In the current study it was possible to demonstrate a higher prevalence of SRB in saliva samples from patients with gastritis and periodontal diseases (22). The methodology applied was more selective in the detection of the site of action of SRB. The presence of SRB in different dental tissues with distinct periodontal features demonstrates that new studies need to be developed in order to determine the true role of SRB in the oral microbiota. In addition, it was possible to verify the presence of Lactobacillus casei together with SRB in one sample.

\section{Acknowledgements}

The authors gratefully acknowledge the patients for their participation in this study. This work was supported by the Foundation for Post-Graduate Education (CAPES), and the National Institute of Technology (LABIO and DCOR).

\section{Conflict of interest}

The authors declare that they have no conflict of interest.

\section{Abstract}

Aim: To detect for the presence of sulphate-reducing bacteria (SRB) and evaluate the possible as sociation between SRB and cultivable facultative bacterial of oral sites with different periodontal conditions. Methods: The study was carried out on 9 samples from different oral sites in $8 \mathrm{pa}$ tients (two samples were collected from the same patient). Material was collected using modified Postgate E culture medium, indicated for the growth and isolation of SRB. In addition, a reducing solution for anaerobic bacteria was used as a transport solution for facultative bacteria and identified by polymerase chain reaction amplification (PCR) and sequencing of the $16 \mathrm{~S}$ rRNA gene. Results: SRB was found in 3 patient samples: the first in a root fragment, the second in a root fragment and a healthy tooth with vertical bone loss and a mobility degree of 3 ; and the third in a healthy tooth extracted for orthodontic treatment. In the final patient, the cultivable facultative species Lactobacillus casei was identified. Other facultative bacterial species were identified in patient 5 (Kurthia Gibsonii) and patient 7 (Pseudomonas aeruginosa). Conclusions: The detection of SRB in different dental tissues with distinct periodontal features demonstrated that new studies need to be developed in order to determine the true role of SRB in the oral microbiota. In addition, it was possible to verify the presence of Lactobacillus casei together with SRB in one sample.
Received: May 16, 2013

Accepted: January 30, 2014

Address for correspondence Dr. Fabiano Luiz Heggendorn Rua Feliz da Cunha 11, ap. 806, Tijuca. CEP 20260-300, Rio de Janeiro. Tel. (21) 94119341.

fabianohegg@gmail.com

Key words

Periodontitis; Sulphur-Reducing Bacteria, Desulfovibrio.

\section{References}

1. Postgate JR - editor. The Sulphate-reducing bacteria. $2^{\text {nd }}$ ed. London: Cambridge; 1984.

2. Bozo-Hurtado L, Gracía-Amado MA, Chistoserdov A, Varela R, Narvaez JJ, Colwell R et al. Identification of bacteria in enrichment cultures of sulfate reducers in the cariaco basin water column employing Desnaturing Gradient Gel Electrophoresis of 16S ribosomal RNA gene fragments. Aquatic Biosystems. 2013 Aug 28;9(1):17.

3. Heggendorn FL, Gonçalves LS, Lutterbach MTS, Dias EP. Physiologic and pathological processes of the sulphate-reducing bactéria of the genus Desulfovibrio sp. Brasília Med. 2009;46:247252.
4. Sefer M, Cãlinescu I. Sulfate-reducing bacteria (genus Desulfovibrio) isolated from dental caries in humans. Microbiol Parazitol Epidemiol (Bucur). 1969 May-Jun;14(3):231-5.

5. Willis CL, Gibson GR, Holt J, Allison C. Negative correlation between oral malodour and numbers and activities of sulphatereducing bacteria in the human mouth. Arch Oral Biol. 1999 Aug;44(8):665-70.

6. Boopathy R, Robichaux M, Lafont D, Howell M. Activity of sulfatereducing bacteria in human periodontal pocket. Can J Microbiol. 2002 Dec;48(12):1099-103.

7. Langendijk PS, Hanssen JTJ, Van Der Hoeven JS. Sulfate-reducing bacteria in association with human periodontits. J Clin Periodontal. 2000 Dec;27(12):943-50. 
8. Langendijk PS, Kulik EM, Sandmeier H, Meyer J, Van Der Hoeven JS. Isolation of Desulfomicrobium orale sp. nov. and Desulfovibrio strain NY682, oral sulfate-reducing bacteria involved in human periodontal disease. International Journal of systematic and evolutionary microbiology. 2001;51:1035-1044.

9. Robichaux M, Howell M, Boopathy R. Growth and activities of sulfate-reducing and methanogenic bacteria in oral cavity. Curr Microbiol. 2003 Jul;47(1):12-6.

10. Loubinoux J, Bisson-Boutelliez C, Miller N, Le Faou AE. Isola tion of the provisionally named Desulfovibrio Fairfieldensis from human periodontal pockets. Oral Microbiol Immunol. 2002 Oct;17(5):321-3.

11. Bisson-Boutelliez C, Massin F, Dumas D, Miller N, Lozniewski A. Desulfovibrio spp. Survive withi KB cells and modulate inflammatory responses. Mol Oral Microbiol. 2010 Jun;25(3):226-35.

12. Dzierżewicz Z, Szczerba J, Lodowska J, Wolny D, Gruchlik A, Orchel A et al. The role of Desulfovibrio desulfuricans lipopolysaccharides in modulation of periodontal inflammation through stimulation of human gingival fibroblasts. Arch Oral Biol. 2010 Jul;55(7):515-22.

13. Campbell AG, Campbell JH, Schwientek P, Woyke T, Sczyrba A, Allman $S$ et al. Multiple Single-cell Genomes Provide Insight into Functions of Uncultured Deltaprotobacteria in the Human Oral Cavity. PLoS ONE. 2013;8(3):e59361.

14. Langendijk-Genevaux PS, Grimm WD, Van Der Hoeven JS. Sulfate-reducing bacteria in relation with other potential periodontal pathogens. J Clin Periodontol. 2001 Dec;28(12):1151-7.
15. Remoundaki E, Kousi P, Joulian C, Battaglia-Brunet F, Hatzikioseyian A, Tsezos M. Characterization, morphology and composition of biofilm and precipitates from a sulphate-reducing fixedbed reactor. J Hazard Mater. 2008 May 1;153(1-2):514-24.

16. Larry, LB; Hamilton, WA - editors. Sulphate-reducing Bacteria Environmental and engineered systems. New York: Cambridge University Press; 2007.

17. Schaechter, $M$ - editor. The Desk encyclopedia of microbiology. $2^{\text {nd }}$ ed. San Diego: Elsevier Academic Press; 2009.

18. Quevedo B, Giertsen E, Zijnge V, Lüthi-Schaller H, Guggenheim B, Thurnheer T et al. Phylogenetic group- and species-specific ologonucleotide probes for single-cell detection of lactic acid bacteria in oral biofilms. BMC Microbiol. 2011 Jan 19;11:14.

19. Schaechter, $M$ - edotor. Encyclopedia of Microbiology. $3^{\text {rd }}$ ed. San Diego: Elsevier; 2009.

20. Marquet P, Duncan SH, Chassard C, Bernalier-Donadille A, Flint HJ. Lactate has the potential to promote hydrogen sulphide formation in the human colon. FEMS Microbiol Lett. 2009 Oct;299(2):128-34

21. Newton DF, Cummings JH, Macfarlane S, Macfarlane GT. Growth of a human intestinal Desulfovibrio desulfuricans in continuous cultures containing defined populations of saccharolytic and amino acid fermenting bacteria. J Appl Microbiol. 1998 Aug;85(2):372-80.

22. Heggendorn FL, Gonçalves LS, Dias EP, Silva junior A, Galvão MM, Lutterbach MTS. Detection of sulphate-reducing bacteria in human saliva. Acta Odontol Scand. 2013 Nov;71(6):1458-63. 